\title{
Multi-scale spatial variations in benthic sediment geochemistry and macrofaunal communities under a suspended mussel culture
}

\author{
Myriam D. Callier ${ }^{1,2}$, Christopher W. McKindsey ${ }^{1,2, *}$, Gaston Desrosiers $^{2}$ \\ ${ }^{1}$ Ocean and Environmental Sciences Division, Maurice Lamontagne Institute, Fisheries and Oceans Canada, PO Box 1000, \\ Mont Joli, Quebec G5H 3Z4, Canada \\ ${ }^{2}$ Institut des Sciences de la Mer, Université du Québec à Rimouski, 310 allée des Ursulines, CP 3300, Rimouski, \\ Quebec G5L 3A1, Canada
}

\begin{abstract}
The chemical and biological effects of biodeposition from a mussel culture were evaluated at multiple spatial scales during the summer of 2003 in Great-Entry Lagoon, eastern Canada. Sediment samples were collected directly under and between mussel lines (positions $10 \mathrm{~m}$ apart: $10 \mathrm{~m}$ scale) from multiple sites (located ca. $100 \mathrm{~m}$ apart: $100 \mathrm{~m}$ scale) in each of 3 zones: reference (R), $0+$ and 1+ mussel cohort zones (located at least $500 \mathrm{~m}$ apart: km scale). In general, redox potential decreased and sulphide concentration increased with sediment depth but did not differ among zones or positions. A clear difference in macrofaunal community structure was observed among $\mathrm{R}, 0+$ and $1+$ zones, as well as between the positions directly under mussel lines in $1+$ sites $\left(1+{ }_{\text {under }}\right)$ and those between $1+$ mussel lines $(1+$ between $)$. The benthic community at $1+_{\text {under }}$ positions was dominated by an opportunistic species (Capitella capitata) and had the lowest diversity and biomass. 0+ sites were characterised by the greatest number of species and biomass, suggesting that some species have benefited from a moderate organic loading from the 0+ mussels. Historical data indicate that the deeper part of the lagoon was a naturally enriched environment. The mussel farm probably contributes to local organic enrichment. Comparison of benthic communities from the present study ( $>20 \mathrm{yr}$ after the initiation of mussel aquaculture) in the site to similar historical data from 3 periods (1975 and 1978, before mussel farming; 1982, at the start of farming activities; and 2004, after the 1+ mussel harvest) showed that community structure differed largely because of the greater abundance of deposit feeders in 2003. However, among these 3 periods the differences in benthic community structure were no greater than differences observed between years within the periods.
\end{abstract}

KEY WORDS: Aquaculture · Biodeposition · Organic enrichment $\cdot$ Redox potentials $\cdot$ Sulphide Macrofaunal community structure $\cdot$ Spatial scale

\section{INTRODUCTION}

Aquaculture production is increasing worldwide, as are concerns about its influence on the environment (see Hargrave 2005). Suspension-feeding bivalves produce biodeposits (faeces and pseudofaeces) that have greater sinking velocities than their constituent particles (Haven \& Morales-Alamo 1966). Consequently, bivalve biodeposition may increase sedimentation rates under culture sites (by a factor of 1.3 to 5.5; see
Hatcher et al. 1994, Callier et al. 2006, Giles et al. 2006). The accumulation of biodeposits under suspended bivalve culture may lead to local organic enrichment and potentially increased oxygen uptake and ammonium release (Hatcher et al. 1994), sulphate reduction (Dahlbäck \& Gunnarsson 1981) and changes in benthic community structure (Mattsson \& Lindén 1983, Kaspar et al. 1985).

According to the general model of organic enrichment outlined by Pearson \& Rosenberg (1978), macro- 
benthic communities subject to increased organic loading will exhibit decreased species richness, increased abundance because of the dominance of opportunistic species, a decrease of total biomass, and shifts in the dominance of trophic groups (Weston 1990). For example, subsurface deposit feeders are expected to become increasingly dominant with increasing organic enrichment (Pearson \& Rosenberg 1978). However, studies on the influence of suspended bivalve culture on the benthic environment do not show consistent effects. While some studies have observed a lower total number of individuals, a lower species richness (Mattsson \& Lindén 1983, Kaspar et al. 1985, Chamberlain et al. 2001), and a dominance of opportunistic species at mussel farms compared to reference sites (Chamberlain et al. 2001: Site 2), others have not detected significant differences (Chamberlain et al. 2001: Site 1, Miron et al. 2005). In some cases, 'non classical eutrophication responses,' such as greater Shannon-Wiener diversity index measures and biomass, have been observed at mussel farm sites (e.g. Grant et al. 1995) due to the presence of scavengers attracted by mussel drop-off. Differing effects may be explained in part by site (hydrodynamics, topography, background enrichment, sediment type) and culture (bivalve density, culture depth, mussel size) differences. Together, these factors may influence biodeposit production and dispersion (Giles \& Pilditch 2004, Callier et al. 2006) and therefore their potential impact on the benthic environment.

In this study, we evaluated the influence of suspended mussel Mytilus edulis L. culture on the chemical and biological benthic environment of Great-Entry Lagoon (GEL), Magdalen Islands, eastern Canada. At this site, Callier et al. (2006) observed that sedimentation rates directly under lines with mussels at least $1 \mathrm{yr}$ old (1+) were twice those in areas $10 \mathrm{~m}$ distant, between the lines, and in other zones studied, i.e. sites with mussels less than $1 \mathrm{yr}$ old $(0+)$ and reference sites outside the mussel farm (R). It was predicted that the benthic condition in GEL will vary in relation to observed differences in organic sedimentation. Although several studies have examined the influence of bivalve culture on benthic environments, few have evaluated smaller-scale variations in benthic characteristics within a culture site (1) under long lines vs. between long lines or (2) in areas with juvenile bivalves (i.e. at the beginning of the growth cycle) vs. bivalves of commercial size. Such variation should be taken into account when evaluating the influence of bivalve culture on the benthic environment and when determining the environmental carrying capacity of sites for bivalve aquaculture.

The objective of this study therefore was to determine the influence of the mussel farm in GEL on the benthic environment at several spatial scales: $10 \mathrm{~m}$ scale (samples were taken at positions directly under mussel lines and $10 \mathrm{~m}$ distant, directly between mussel lines), $100 \mathrm{~m}$ scale (among multiple sites separated by ca. $100 \mathrm{~m}$ within each of 3 zones), and $1 \mathrm{~km}$ scale (among 0+, 1+ and R zones, which are separated by $>500 \mathrm{~m}$ ). Sites were sampled at the $100 \mathrm{~m}$ scale to ensure the generality of the findings in GEL. We assessed effects in terms of both chemical (redox potential, sulphide concentration and percent organic matter [\%OM]) and biological (diversity, abundance, biomass, and community and trophic group structure) characteristics. The chemical indicators examined were chosen because these have been described as the most sensitive physicochemical indicators of organic enrichment (Hargrave et al. 1997). Further, we compared the benthic community data from the current study with similar historical data in the study area to evaluate the longterm temporal changes in benthic community structure to better understand the importance of bivalve culture in influencing benthic communities.

\section{MATERIALS AND METHODS}

Study site. The mussel farm studied is located in GEL in the Magdalen Islands, eastern Canada $\left(47^{\circ} 37^{\prime} \mathrm{N}\right.$, $\left.61^{\circ} 31^{\prime} \mathrm{W}\right)$ (Fig. 1). Detailed environmental conditions in the lagoon are provided in Callier et al. (2006). The farm covers a total surface area of ca. $2.5 \mathrm{~km}^{2}$, has been in operation for about $23 \mathrm{yr}$ and produces about $180 \mathrm{t}$ of mussels annually. The 1+ mussels attain market size (5 to $6 \mathrm{~cm}$ ) and are harvested and replaced by juveniles each fall. Thus the farm is divided into 2 zones which are stocked with either $0+$ or $1+$ mussel cohorts, the age classes in a zone alternating between years. Each zone contains ca. 200, $91 \mathrm{~m}$ longlines spaced $20 \mathrm{~m}$ apart. Water depth in the sampling area ranged from 5 to $7 \mathrm{~m}$. During the sampling period, average surface temperature and salinity were, respectively, $18^{\circ} \mathrm{C}$ and $31 \mathrm{psu}$. The average water current velocity (at $4 \mathrm{~m}$ depth) during the summer of 2003 was $5 \mathrm{~cm} \mathrm{~s}^{-1}$ with a maximum of $18 \mathrm{~cm} \mathrm{~s}^{-1}$ (Callier et al. 2006).

Sampling design. The study was conducted in summer (August 2003), when biodeposit production is likely to be maximal (Hatcher et al. 1994). Variations in sediment characteristics and benthic communities were evaluated at 3 spatial scales. At the largest scale (zones separated by at least $500 \mathrm{~m}$ : $\mathrm{km}$ scale), samples were collected in each of the 2 farm zones $(0+$ and $1+)$ and $R$ (Fig. 1). In order to account for natural variation in benthic characteristics, samples were taken in each of 4 randomly chosen sites separated by ca. $100 \mathrm{~m}$ within each zone (100 m scale). During the sampling period, we observed that one of the $4 \mathrm{R}$ sites (the most northern 


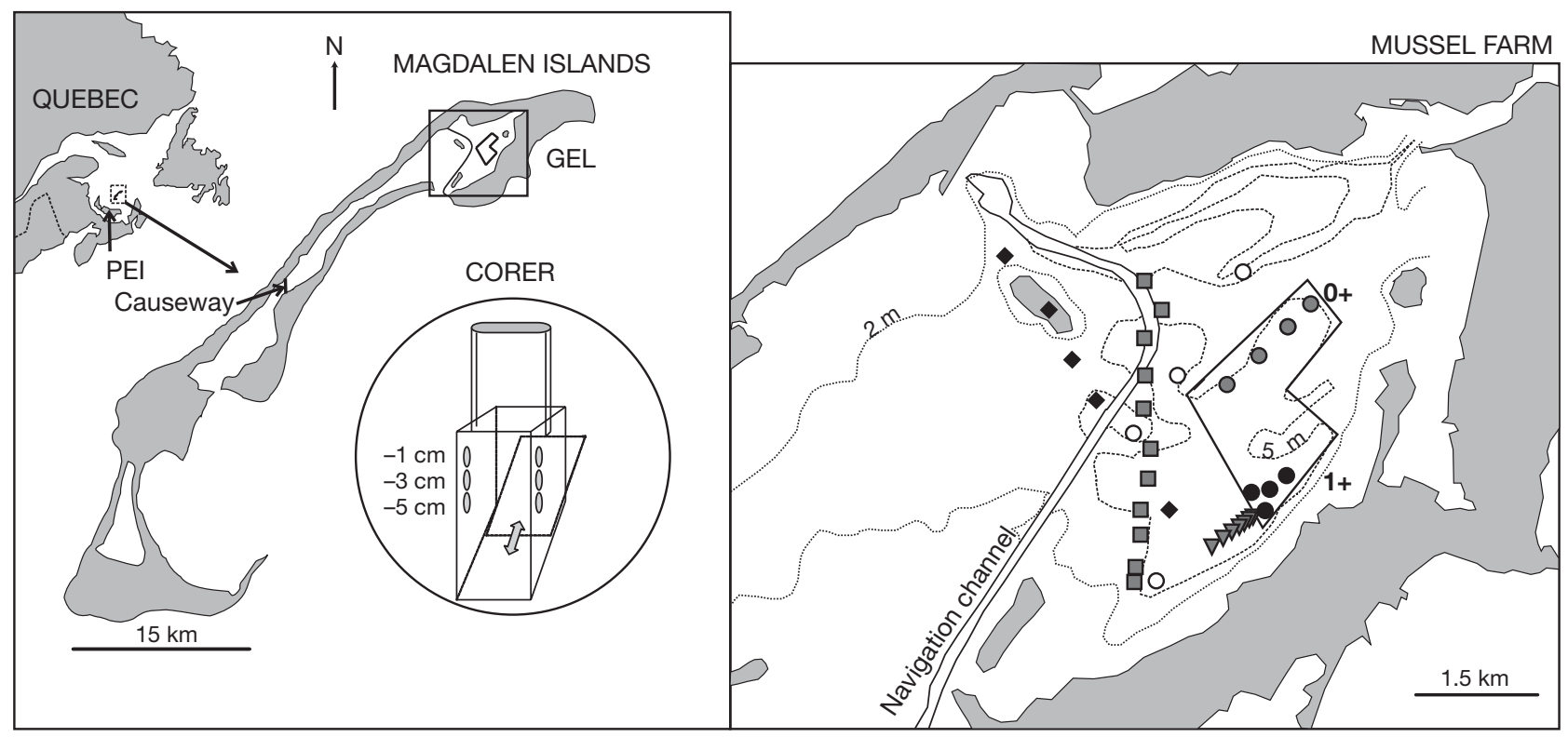

Fig. 1. Mussel farm (dotted polygon) in Great-Entry Lagoon (GEL) in the Magdalen Islands, Canada. The farm is divided into 2 zones based on the age classes of mussels within them: 0+ (less than $1 \mathrm{yr}$ old, O); $1+($ greater than $1 \mathrm{yr}$ old, $\bullet$ ). O: reference sites. At each site, 3 core replicates were taken both directly under and between the mussel lines. Sampling sites from historical studies: $(\bullet), 1975$; $(\square), 1978$; and $(\nabla), 2004$. Sampling sites in 1982 were situated within the mussel farm but their exact positions are unknown. PEI: Prince Edward Island

site) was situated in a depositional zone for detritic seagrass Zostera marina and macroalgae. We thus decided to remove this site from subsequent analyses.

To evaluate the small-scale influence of the mussel farm, samples were taken directly under mussel lines (i.e. $0+_{\text {under }}$ and $1+_{\text {under }}$ ) and at positions $10 \mathrm{~m} \mathrm{NW}$ of these, directly between the mussel lines (i.e. $0+_{\text {between }}$ and $\left.1+_{\text {between }}\right)$. The same sampling design was used at both mussel and $\mathrm{R}$ sites to allow for comparisons of small-scale spatial patterns in different zones. Thus, 'under' and 'between' positions in $0+$ and $1+$ zones correspond to SE and NW positions at reference sites, respectively (i.e. $R_{\text {under }}$ and $R_{\text {between }}$ positions) . At each position, 3 replicates were sampled using a wedge corer (Fig. 1) with a vertical array of pre-drilled holes in the sides of the corer to take sediment sub-samples at $-1,-3$ and $-5 \mathrm{~cm}$ sediment depths to determine chemical sediment characteristics. Samples were taken by SCUBA divers to ensure that the cores were returned to the surface as undisturbed as possible.

Sedimentation rates. Callier et al. (2006) evaluated sedimentation rates in GEL from June to September 2003. In sum, greater sedimentation was observed in the $1+_{\text {under }}$ position than in all other positions (which did not differ) in June. This trend changed as $0+$ mussels grew and 1+ mussels were harvested to a situation where sedimentation was greatest in $0+_{\text {under }}$ positions in August and September.

Sediment geochemical characteristics. Redox potentials $\left(\mathrm{Eh}, \mathrm{mV}, 2\right.$ replicates depth ${ }^{-1} \mathrm{core}^{-1}$ ) were measured in the field, directly from the sediment core, using a combined reference and platinum redox electrode. The redox probe was calibrated using Zobell's solution. Eh was expressed as $\mathrm{mV}$ at ambient temperature relative to a normal hydrogen electrode $\left(\mathrm{Eh}_{\mathrm{NHE}}\right)$. A cut off, $5 \mathrm{ml}$ plastic syringe was pushed through holes at each depth to obtain sediment sub-samples. Sediment sulphide concentration $\left(\mu \mathrm{M}, 2\right.$ replicates depth ${ }^{-1}$ core $^{-1}$ ) was determined using an Orion ${ }^{\circledR}$ silver/silver sulphide electrode with a combined calomel electrode as reference. A sulphide anti-oxidant buffer solution was added to each sediment sub-sample. The analysis was done in the field and when storage was required for a short period of time $(<3 \mathrm{~h})$, samples were placed on ice in the dark. Details of the methodology used are provided in Wildish et al. (1999). Sediment \%OM was calculated as the weight loss of dried material combusted at $450^{\circ} \mathrm{C}$ for $5 \mathrm{~h}$ (Byers et al. 1978).

Macrofaunal community analysis. The corer sampled an area of $263 \mathrm{~cm}^{2}$ to a depth of ca. $15 \mathrm{~cm}$. Samples were gently sieved through a $500 \mu \mathrm{m}$ mesh. The material retained on the sieve was preserved in a $5 \%$ formaldehyde-saline solution. Infaunal specimens were stored in $70 \%$ ethanol after sorting. Identifications were done to the lowest taxonomic level possible, usually to species. Sites were characterised in terms of total abundance, total biomass and diversity (number of species per site, $S_{\text {; }}$ Shannon-Wiener diversity index, $H^{\prime}$; and equitability, $J^{\prime}$ ). The biomass of each species was measured as blotted wet weight. All individuals of 
a species in a core were grouped for biomass measurements. Animals were removed from tubes prior to biomass determination but the biomass of molluscs includes their shell weight (Weston 1990).

Statistical analysis. Variations in redox potential, sulphide, \%OM and univariate indices of the benthic communities were evaluated using ANOVA followed by Tukey multiple comparison tests with SYSTAT. Data were transformed when necessary to satisfy the assumptions of the statistical model (see Results for details). Nonparametric multivariate analyses of community structure, including multi-dimensional scaling (MDS), and SIMPER analyses (to determine the contribution of each species to the total similarity among samples within a given zone) were performed using PRIMER. Analyses were done using individual cores as replicates. Variation in benthic community structure was evaluated using DISTLM (a distance-based nonparametric multivariate analogue of ANOVA) (Anderson \& Ter Braak 2003). Multivariate pair-wise comparisons were done using ANOSIM. Data were $\sqrt{ }$-transformed for all multivariate analyses. Species were classified into trophic groups according to the classification available in the literature (e.g. Word 1990).

Inter-annual comparison. The community structure based on abundance data observed in the present study (following $>20$ yr of mussel aquaculture) was compared to similar data from 3 periods: (1) before the farm was established, in 1975 (Bourget 1976, Bourget \& Messier 1982: $625 \mathrm{~cm}^{2}$ grab samples sieved on a $500 \mu \mathrm{m}$ screen) and 1978 (J. Munro unpubl. data: $560 \mathrm{~cm}^{2}$ grab samples sieved on a $500 \mu \mathrm{m}$ screen); (2) at the start of farming activities, in 1982 (Élouard et al. 1983: 625 and $1000 \mathrm{~cm}^{2}$ grab samples sieved on a $1 \mathrm{~mm}$ screen); and (3) after the mussels in the 1+ zone were harvested, in 2004 (M. D. Callier et al. unpubl. data: $78.5 \mathrm{~cm}^{2}$ core samples sieved on a $500 \mu \mathrm{m}$ screen). In all but one case (Élouard et al. 1983), the raw georeferenced data was available and provided by the appropriate authors (see Fig. 1). In the case of Élouard et al. (1983), only means of 8 samples from the general area within the present culture site on each of 3 sampling dates (June, August and October) were available from the publication. In all other cases, sampling was done in August. Because of taxonomic inconsistencies among the different data sets, the combined data set was reduced such that each taxa was at the same level of taxonomic resolution. Thus, although most taxa were identified to the species level, some were grouped at higher taxonomic levels (e.g. Capitellidae). For 2003 and 2004, replicate samples within a position were pooled to obtain surface sampling areas that were similar to those sampled in 1975 and 1978 (i.e. $3 \times$ $263 \mathrm{~cm}^{2}$ replicates $=789 \mathrm{~cm}^{2}$ for 2003 and $5 \times 78.5 \mathrm{~cm}^{2}$ replicates $=392.5 \mathrm{~cm}^{2}$ for 2004). All data were then transformed to number of ind. $\mathrm{m}^{-2}$ prior to analysis. Because of inconsistencies among data sets, trends are only compared graphically (MDS analysis) and with respect to trophic groupings.

\section{RESULTS}

\section{Sediment geochemical characteristics}

Sediment redox potentials, sulphide concentrations and $\% \mathrm{OM}$ did not differ among zones $(0+, 1+$ and $\mathrm{R})$ or between positions (under vs. between), but all measurements varied significantly with depth (Table 1). The greatest sulphide concentrations and the lowest redox potentials were recorded at -3 and $-5 \mathrm{~cm}$ (Fig. 2). \%OM decreased significantly with increasing sediment depth (Table 1, Fig. 2). A uniform black colour was observed throughout all sediment cores.

Table 1. ANOVA results for sulphide concentration $(\mu \mathrm{M})$, redox potential $\left(\mathrm{Eh}_{\mathrm{NHE}}, \mathrm{mV}\right)$ and percentage organic matter (log OM) measured within and outside the mussel farm in Great-Entry Lagoon in the summer 2003. Fixed factors were zone (Z), position

(PO) and depth (DE). Random factor was site (SI). See 'Results' for details. Statistically significant values indicated in bold

\begin{tabular}{|c|c|c|c|c|c|c|c|c|c|c|c|}
\hline \multirow{2}{*}{$\begin{array}{l}\text { Sources of } \\
\text { variations }\end{array}$} & \multirow[b]{2}{*}{$\mathrm{df}$} & \multicolumn{3}{|c|}{ Sulphide $(\mu \mathrm{M})$} & \multicolumn{3}{|c|}{ Redox potential (mV) } & \multirow[b]{2}{*}{$\mathrm{df}$} & \multicolumn{3}{|c|}{$\log \mathrm{OM}$} \\
\hline & & MS & $F$ & $\mathrm{p}$ & MS & $F$ & $\mathrm{p}$ & & MS & $F$ & $\mathrm{p}$ \\
\hline $\mathrm{Z}$ & 2 & 3152809 & 1.419 & 0.304 & 8951 & 0.496 & 0.629 & 2 & 0.123 & 0.815 & 0.476 \\
\hline SI (Z) & 7 & 2222241 & 5.386 & 0.000 & 18064 & 12.594 & 0.000 & 8 & 0.151 & 13.860 & 0.000 \\
\hline $\mathrm{PO}$ & 1 & 870843 & 0.632 & 0.453 & 1088 & 0.232 & 0.645 & 1 & 0.003 & 0.500 & 0.500 \\
\hline $\mathrm{DE}$ & 2 & 4575458 & 16.100 & 0.000 & 23324 & 21.072 & 0.000 & 2 & 0.064 & 4.267 & 0.033 \\
\hline $\mathrm{Z} \times \mathrm{PO}$ & 2 & 4081792 & 2.960 & 0.117 & 8370 & 1.783 & 0.237 & 2 & 0.002 & 0.333 & 0.726 \\
\hline $\mathrm{Z} \times \mathrm{DE}$ & 4 & 637374 & 2.243 & 0.117 & 1665 & 1.504 & 0.254 & 4 & 0.028 & 1.867 & 0.166 \\
\hline $\mathrm{PO} \times \mathrm{SI}(\mathrm{Z})$ & 7 & 1378945 & 3.342 & 0.002 & 4693 & 3.272 & 0.003 & 8 & 0.006 & 0.534 & 0.827 \\
\hline $\mathrm{DE} \times \mathrm{SI}(\mathrm{Z})$ & 14 & 284185 & 0.689 & 0.783 & 1107 & 0.772 & 0.699 & 16 & 0.015 & 1.352 & 0.195 \\
\hline $\mathrm{PO} \times \mathrm{DE}$ & 2 & 184717 & 0.782 & 0.477 & 3485 & 1.886 & 0.188 & 2 & 0.025 & 1.667 & 0.220 \\
\hline $\mathrm{Z} \times \mathrm{PO} \times \mathrm{DE}$ & 4 & 140119 & 0.593 & 0.673 & 1363 & 0.738 & 0.582 & 4 & 0.018 & 1.200 & 0.349 \\
\hline $\mathrm{DE} \times \mathrm{PO} \times \mathrm{SI}(\mathrm{Z})$ & 14 & 236309 & 0.573 & 0.884 & 1848 & 1.288 & 0.219 & 16 & 0.015 & 1.404 & 0.168 \\
\hline Error & 176 & 412599 & & & 1434 & & & 65 & 0.011 & & \\
\hline
\end{tabular}



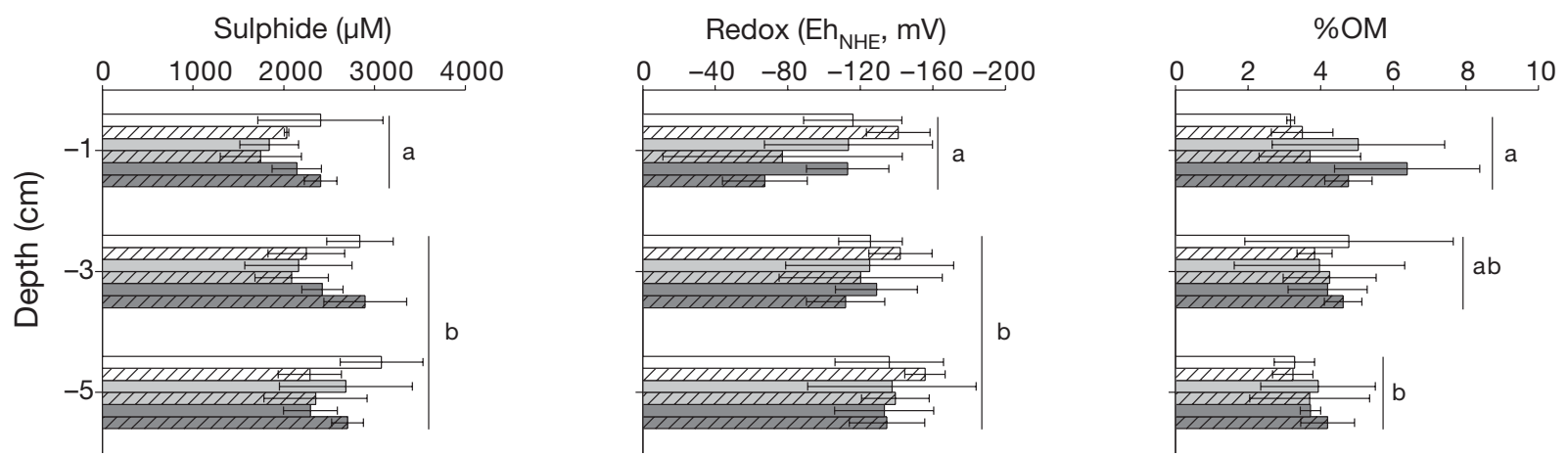

Fig. 2. Sediment depth-specific sulphide concentration $(\mu \mathrm{M})$, redox potential $\left(\mathrm{Eh}_{\mathrm{NHE}} \mathrm{mV}\right)$ and percentage organic matter $(\%$ OM) (average $\pm \mathrm{SD}, \mathrm{n}=3-4$ ). Zones $=\mathrm{R}$ (white), 0+ (light grey) and 1+ (dark grey) zones. Positions = under the line (solid colours), between the lines (hatched). Results from the corresponding ANOVAs are given in Table 1
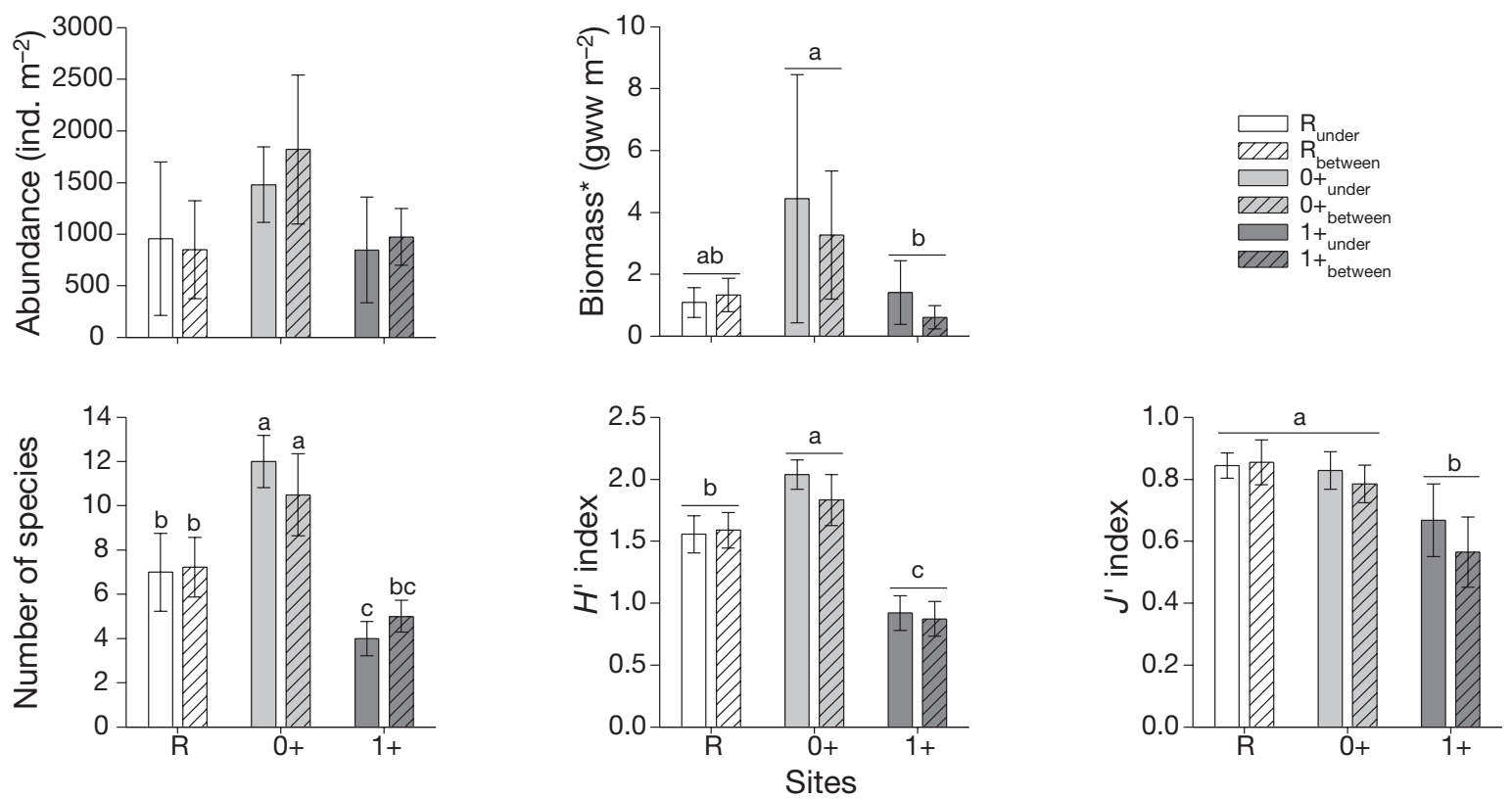

Fig. 3. Macrofaunal characteristics from 3 zones and 2 positions (average $\pm S D, n=3-4$ ). Note that Abundance and Biomass ${ }^{*}$ are expressed as a function of $\mathrm{m}^{-2}$ and that Biomass* includes only those organisms $<100 \mathrm{mg}$ wet wt (see 'Results' for details). Results from the corresponding ANOVAs are given in Table 2. Significant differences among groups as identified by pair-wise contrasts are indicated by different letters. $H^{\prime}$ and $J^{\prime}$ : Shannon-Wiener diversity and equitability, respectively

\section{Benthic community}

\section{Abundance and biomass}

The mean abundance of organisms was 1177 ind. $\mathrm{m}^{-2}$, ranging from 280 to 2560 ind. $\mathrm{m}^{-2}$. Although a visual inspection of the data (Fig. 3) suggests that abundance was greatest in the $0+$ zone, this effect was not statistically significant (Table 2). Biomass differed significantly among zones (Table 2) such that the greatest biomass was observed in the $0+$ zone and the lowest in the $1+$ zone. However, part of this pattern was driven by the presence of 6 large individuals (Ensis directus, Nereis virens, Glycera dibranch- iata and 3 Yoldia limatula with body mass ranging from 100 to $10^{4} \mathrm{mg}$ wet $\mathrm{wt}$ ) within separate replicates. As the sampling protocol was not designed to sample this size class of organism (see Andrew \& Mapstone 1987), these organisms were removed from the data set and the analysis rerun (see biomass* in Table 2). The new analysis supported the original results (Fig. 3).

\section{Species diversity}

A total of 45 species was observed. The number of species observed was a function of the interaction 
Table 2. ANOVA results for macrofauna characteristics: abundance, biomass, biomass* (without rare individuals weighing $>100 \mathrm{mg}$ ), Number of species core ${ }^{-1}$, Shannon-Wiener diversity $H^{\prime}$ and equitability $J^{\prime}$ indices observed at GEL during summer 2003. Fixed factors were zone (Z) $(0+, 1+, \mathrm{R})$ and position (PO) (under and between the mussel lines). Site (SI) was a random factor (4 sites in $0+$ and $1+$ and 3 sites in reference: R). Abundance and biomass data were $(\log x+1)$ transformed to satisfy the assumptions of the statistical model

\begin{tabular}{|c|c|c|c|c|c|c|c|c|c|c|}
\hline \multirow{3}{*}{$\begin{array}{l}\text { Source of } \\
\text { variation }\end{array}$} & \multirow{3}{*}{$\begin{array}{r}\mathrm{df} \\
2\end{array}$} & MS & F & $\mathrm{p}$ & MS & & $\mathrm{p}$ & MS & $F$ & $\mathrm{p}$ \\
\hline & & \multicolumn{3}{|c|}{ Log abundance } & \multicolumn{3}{|c|}{ Log biomass } & \multicolumn{3}{|c|}{ Log biomass ${ }^{*}$} \\
\hline & & 0.727 & 3.847 & 0.068 & 1.194 & 5.686 & 0.029 & 0.672 & 9.205 & 0.008 \\
\hline SI $(Z)$ & 8 & 0.189 & 3.259 & 0.005 & 0.210 & 0.955 & 0.483 & 0.073 & 0.890 & 0.533 \\
\hline $\mathrm{PO}$ & 1 & 0.092 & 1.278 & 0.291 & 0.473 & 2.867 & 0.129 & 0.008 & 0.108 & 0.751 \\
\hline $\mathrm{Z} \times \mathrm{PO}$ & 2 & 0.008 & 0.111 & 0.896 & 0.134 & 0.812 & 0.477 & 0.032 & 0.432 & 0.663 \\
\hline $\mathrm{PO} \times \mathrm{SI}(\mathrm{Z})$ & 8 & 0.072 & 1.241 & 0.299 & 0.165 & 0.750 & 0.648 & 0.074 & 0.902 & 0.523 \\
\hline \multirow[t]{2}{*}{ Error } & 43 & 0.058 & & & 0.220 & & & 0.082 & & \\
\hline & & \multicolumn{3}{|c|}{ Number of species $S$} & \multicolumn{3}{|c|}{ Shannon $H^{\prime}$} & \multicolumn{3}{|c|}{ Equitability $J^{\prime}$} \\
\hline Z & 2 & 277.243 & 35.412 & 0.000 & 6.617 & 79.723 & 0.001 & 0.336 & 18.667 & 0.000 \\
\hline SI (Z) & 8 & 7.829 & 1.260 & 0.289 & 0.083 & 0.449 & 0.885 & 0.018 & 0.783 & 0.620 \\
\hline $\mathrm{PO}$ & 1 & 0.194 & 0.092 & 0.770 & 0.086 & 1.564 & 0.246 & 0.031 & 1.240 & 0.298 \\
\hline $\mathrm{Z} \times \mathrm{PO}$ & 2 & 9.643 & 4.559 & 0.048 & 0.075 & 1.364 & 0.309 & 0.016 & 0.640 & 0.552 \\
\hline $\mathrm{PO} \times \mathrm{SI}(\mathrm{Z})$ & 8 & 2.115 & 0.340 & 0.945 & 0.055 & 0.297 & 0.963 & 0.025 & 1.087 & 0.390 \\
\hline Error & 43 & 6.213 & & & 0.185 & & & 0.023 & & \\
\hline
\end{tabular}

between zone and position (Table 2), such that the greatest number of species was recorded in the $0+$ zone and the lowest in the 1+ zone, with a trend for greater and lesser richness directly under lines in the
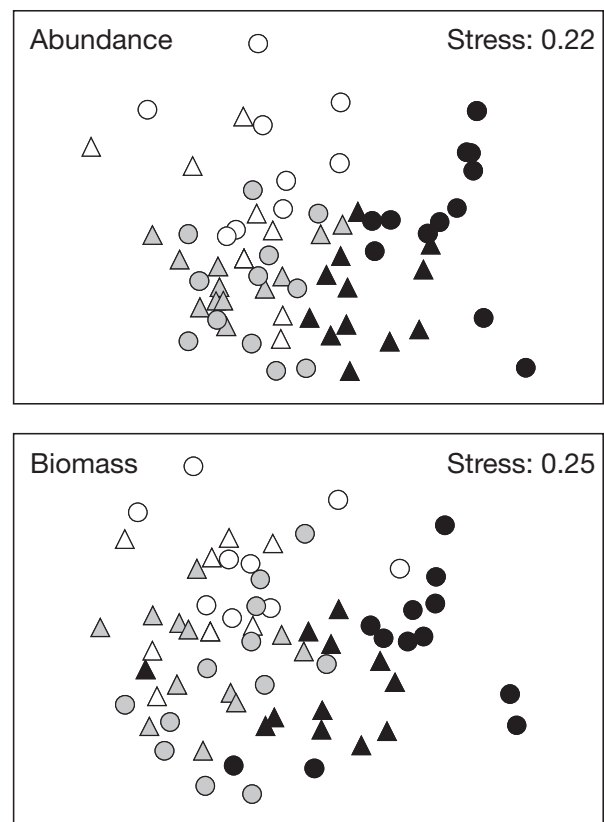

Fig. 4. Non-metric multi-dimensional scaling illustrating variation in community structure $(\sqrt{ }$-transformed) among $R$ (white), 0+ (grey) and 1+ (black) zones in both between (triangles) and under (circles) mussel line positions. Results from the corresponding DISTLM analysis are given in Table 3 and pair-wise comparisons (ANOSIM) in Table 4
$0+$ and $1+$ zones, respectively (Fig. 3). Both $H^{\prime}$ and $J^{\prime}$ differed significantly among zones (Table 2 ) such that $H^{\prime}$ was greatest in the $0+$ zone and least in the $1+$ zone and $J^{\prime}$ was least in the 1+ zone (Fig. 3).

\section{Community structure}

Analysis of community structure based on abundance and biomass data showed the same pattern. Samples from $\mathrm{R}, 0+, 1+_{\text {between }}$ and $1+_{\text {under }}$ sites formed clusters that were distinct (Fig. 4) and significantly different (Tables 3,4) from one another. DISTLM analysis showed that, other than variation among replicates, differences among zones explained the greatest proportion of the variation in community structure (Table 3).

The average abundance and biomass of the dominant species as well as their contribution to the similarity among replicates within zones and positions are given in Table 5. In the R zone, Pectinaria granulata, juvenile Macoma calcarea and Polydora ciliata were the most abundant species, while Heteromastus filiformis and $P$. ciliata accounted for the greatest biomass. In the 0+ zone, juvenile M. calcarea, Hydrobia minuta and $P$. granulata were the most abundant species. The greatest biomass was represented by $P$. granulata and Nassarius trivittatus at $0+_{\text {between }}$ positions, whereas juvenile Nereis sp. and Nephtys caeca accounted for most of the biomass at $0+$ under positions. At $1+_{\text {between }}$ positions, juvenile $M$. calcarea and Capitella capitata were the most abundant species and 
Table 3. DISTLM (distance-based multivariate analysis) results for the benthic community structure sampled in GEL in summer 2003. Fixed factors were zone ( $\mathrm{Z}: 0+, 1+, \mathrm{R}=$ reference) and position ( $\mathrm{PO}$, under and between the mussel lines). Site (SI) was a random factor. VE\% indicates the percentage of variation explained by each factor. Analyses based on both total abundance and total biomass data of each species are given. All data were $\sqrt{ }$-transformed prior to analysis

\begin{tabular}{|lrrrrr|}
\hline $\begin{array}{l}\text { Source of } \\
\text { variation }\end{array}$ & df & MS & Pseudo-F & p (perm) & VE\% \\
\hline Abundance & & & & & \\
Z & 2 & 18212.42 & 6.056 & 0.000 & 25.2 \\
SI (Z) & 8 & 3007.39 & 2.137 & 0.000 & 16.6 \\
PO & 1 & 8050.30 & 6.713 & 0.000 & 5.6 \\
Z $\times$ PO & 2 & 4248.26 & 3.543 & 0.000 & 5.8 \\
SI $(Z) \times$ PO & 8 & 1199.21 & 0.852 & 0.823 & 6.6 \\
Residual & 54 & 1407.58 & & & \\
Biomass & & & & & \\
Z & 2 & 19216.78 & 5.054 & 0.000 & 18.1 \\
SI (Z) & 8 & 3802.46 & 1.513 & 0.001 & 14.3 \\
PO & 1 & 8281.34 & 3.871 & 0.000 & 3.9 \\
Z $\times$ PO & 2 & 4519.29 & 2.113 & 0.005 & 4.3 \\
SI (Z) $\times$ PO & 8 & 2139.14 & 0.851 & 0.889 & 8.0 \\
Residual & 54 & 2512.92 & & & \\
\hline
\end{tabular}

represented the greatest biomass. The dominance of these 2 species switched in the $1+{ }_{\text {under }}$ positions, where C. capitata represented $59 \%$ of the total biomass.

\section{Trophic structure}

Of the species observed, 18 were deposit feeders, 8 were suspension feeders (e.g. Spio filicornis, Polycirrus sp. Mya arenaria, Ensis directus, Dyastylis polita), and 8 were carnivores (e.g. Retusa canaliculata, Nephtys caeca, Harmothoe imbricata). All communities were dominated by deposit feeders (Table 6) which accounted for more than $70 \%$ of the total number of individuals in each zone. Suspension feeders accounted for ca. $10 \%$ of the abundance at reference and $0+$ sites.

Table 4. Results of pair-wise comparisons of community structure between Zone and Position using ANOSIM. Upper right half of table compares abundance data, whereas lower half compares biomass data. See text for heading definitions. Statistically significant values are indicated in bold

\begin{tabular}{|lcccccc|}
\hline & $\mathrm{R}_{\text {under }}$ & $\mathrm{R}_{\text {between }}$ & $0+_{\text {under }}$ & $0+_{\text {between }}$ & $1+_{\text {under }}$ & $1+_{\text {between }}$ \\
\hline $\mathrm{R}_{\text {under }}$ & - & 0.444 & $\mathbf{0 . 0 0 9}$ & $\mathbf{0 . 0 2 7}$ & $\mathbf{0 . 0 0 1}$ & $\mathbf{0 . 0 0 1}$ \\
$\mathrm{R}_{\text {between }}$ & 0.191 & - & $\mathbf{0 . 0 0 1}$ & $\mathbf{0 . 0 0 1}$ & $\mathbf{0 . 0 0 1}$ & $\mathbf{0 . 0 0 1}$ \\
$0+_{\text {under }}$ & $\mathbf{0 . 0 3 6}$ & $\mathbf{0 . 0 0 1}$ & - & 0.131 & $\mathbf{0 . 0 0 1}$ & $\mathbf{0 . 0 0 1}$ \\
+ $_{\text {between }}$ & $\mathbf{0 . 0 0 6}$ & $\mathbf{0 . 0 0 1}$ & 0.491 & - & $\mathbf{0 . 0 0 1}$ & $\mathbf{0 . 0 0 1}$ \\
1 $_{\text {under }}$ & $\mathbf{0 . 0 0 1}$ & $\mathbf{0 . 0 0 1}$ & $\mathbf{0 . 0 0 1}$ & $\mathbf{0 . 0 0 1}$ & - & $\mathbf{0 . 0 0 1}$ \\
$1_{\text {between }}$ & $\mathbf{0 . 0 0 1}$ & $\mathbf{0 . 0 0 1}$ & $\mathbf{0 . 0 0 1}$ & $\mathbf{0 . 0 0 1}$ & $\mathbf{0 . 0 0 1}$ & - \\
\hline
\end{tabular}

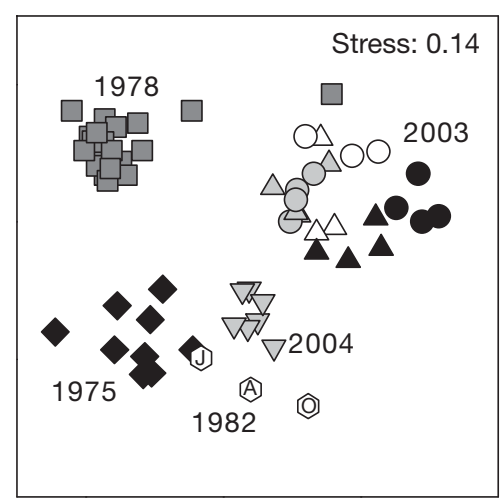

Fig. 5. Non-metric multi-dimensional scaling illustrating variation in historical community structure in GEL. Sample dates include the period prior to the dredging of a navigation channel and the start of mussel farming $(1975,1978)$, after the dredging and at the beginning of farming (1982), and following $>20$ yr of mussel aquaculture (2003 - the current studyand 2004). Years indicated by symbols as in Fig. 1 except for 2003, shown in Fig. 4. Symbols for 1982 indicate the sample date (J: June, A: August, and O: October)

\section{Inter-annual comparison}

MDS analysis showed that benthic community structure differed among years (Fig. 5). However, samples taken from before (1975), at the start of (1982) and after $>20$ yr of mussel culture (2004) in the lagoon were relatively similar and different from samples taken in 1978 and 2003. In fact, comparing samples from 1975, 1982 and 2004 shows that differences in benthic community structure among these 3 periods are no greater than differences observed between years within periods, i.e. before (1975 and 1978) and after (2003 and 2004) the start of mussel culture. The similarity among samples from 1975, 1982 and 2004 can be explained largely by the dominance of the carnivorous gastropod Retusa canaliculata and the extent to which its presence contributes to the within-year similarity among replicates (30-50\%, Table 7). The deposit feeder Tellina agilis was also common in each of those 3 yr. In 1975 and 1982, the benthic community was characterised by a Retusa-TellinaSpisula association and in 2004 by a Retusa-Nassarius-Hydrobia association (Table 7). The 1978 community differed from those in 1975 and 1982 because of the very high abundance of Mya arenaria (33696 ind. $\mathrm{m}^{-2}$ ). Other than M. arenaria, the 1978 benthic community was also characterised by a Retusa-Tellina-Polydora association. The 2003 community was dissimilar to the others largely due to the absence of the suspension feeder Spisula spp. (also absent in 2004) and the 
Table 5. Mean abundance ( $\mathrm{N}$ : ind. $\mathrm{m}^{-2}$ ) and biomass (B: $\mathrm{g} \mathrm{m}^{-2}$ ) of dominant species in $\mathrm{R}, 0+$ and $1+$ zones in both between and under positions. Results of SIMPER analyses identifying species that contribute most to the similarity among replicates within zones and positions are also given (\%). Data were $\sqrt{ }$-transformed. (juv): juvenile specimens; AS: average similarity; ns: species abundance or biomass does not contribute significantly to the similarity among replicates

\begin{tabular}{|c|c|c|c|c|c|c|c|c|c|}
\hline Species & $\mathrm{N}$ & $\%$ & B & $\%$ & Species & $\mathrm{N}$ & $\%$ & B & $\%$ \\
\hline $\mathrm{R}_{\text {between }}$ & \multicolumn{2}{|c|}{$\mathrm{AS}=42.7$} & \multicolumn{2}{|c|}{$\mathrm{AS}=39.8$} & $\mathrm{R}_{\text {under }}$ & \multicolumn{2}{|c|}{$\mathrm{AS}=37.2$} & \multicolumn{2}{|c|}{$\mathrm{AS}=27.1$} \\
\hline Pectinaria granulata & 228 & 17 & 130 & 11 & Pectinaria granulata & 292 & 21 & ns & $\mathrm{ns}$ \\
\hline Macoma calcarea (juv) & 203 & 21 & 58 & 10 & Polydora ciliata & 156 & 24 & 205 & 23 \\
\hline Polydora ciliata & 97 & 27 & 134 & 27 & Macoma calcarea (juv) & 110 & 20 & 22 & 11 \\
\hline Heteromastus filiformis & 89 & 20 & 489 & 41 & Heteromastus filiformis & 97 & 12 & 549 & 45 \\
\hline Mya arenaria (juv) & 59 & 3 & ns & ns & Capitella capitata & 46 & 11 & 124 & 10 \\
\hline Nereis sp. (juv) & ns & ns & 23 & 3 & & & & & \\
\hline $0+_{\text {between }}$ & \multicolumn{2}{|c|}{$\mathrm{AS}=50.7$} & \multicolumn{2}{|c|}{ AS = 29.8} & $0+_{\text {under }}$ & \multicolumn{2}{|c|}{$\mathrm{AS}=44.8$} & \multicolumn{2}{|c|}{$\mathrm{AS}=26.3$} \\
\hline Macoma calcarea (juv) & 463 & 27 & 190 & 19 & Macoma calcarea (juv) & 459 & 26 & 351 & 20 \\
\hline Hydrobia minuta & 371 & 11 & 117 & 7 & Pectinaria granulata & 171 & 15 & 102 & 14 \\
\hline Pectinaria granulata & 260 & 18 & 941 & 22 & Hydrobia minuta & 155 & 5 & 46 & 5 \\
\hline Heteromastus filiformis & 158 & 12 & 247 & 11 & Mya arenaria (juv) & 89 & 11 & 18 & 8 \\
\hline Mya arenaria (juv) & 98 & 4 & ns & ns & Hydrobia sp. & 70 & 5 & 48 & 5 \\
\hline Polydora ciliata & 89 & 7 & 127 & 10 & Nereis sp. (juv) & 67 & 4 & 1475 & 8 \\
\hline Tellina sp. (juv) & 54 & 5 & 12 & 3 & Polydora ciliata & 54 & 6 & 98 & 9 \\
\hline Retusa canaliculata & 51 & 4 & ns & ns & Ensis sp. (juv) & 41 & 7 & 13 & 5 \\
\hline Nassarius trivittatus & ns & ns & 717 & 5 & Heteromastus filiformis & 38 & 4 & 77 & 4 \\
\hline Nereis sp. (juv) & ns & ns & 89 & 4 & Harmothoe imbricata & 35 & 4 & ns & ns \\
\hline \multirow[t]{2}{*}{ Scoloplos armiger } & ns & $\mathrm{ns}$ & 113 & 3 & Nephtys caeca & ns & ns & 618 & 5 \\
\hline & & & & & Ampharete sp. & ns & ns & 54 & 3 \\
\hline $1+_{\text {between }}$ & \multicolumn{2}{|c|}{$\mathrm{AS}=52.7$} & \multicolumn{2}{|c|}{$\mathrm{AS}=35.2$} & $1++_{\text {under }}$ & \multicolumn{2}{|c|}{$\mathrm{AS}=47.6$} & \multicolumn{2}{|c|}{$\mathrm{AS}=31.2$} \\
\hline Macoma calcarea (juv) & 732 & 76 & 78 & 57 & Capitella capitata & 548 & 47 & 781 & 59 \\
\hline Capitella capitata & 44 & 5 & 35 & 11 & Macoma calcarea (juv) & 200 & 46 & 23 & 30 \\
\hline Polydora ciliata & 38 & 6 & ns & ns & & & & & \\
\hline Hydrobia sp. & ns & $\mathrm{ns}$ & 36 & 12 & & & & & \\
\hline Retusa canaliculata & ns & ns & 81 & 8 & & & & & \\
\hline
\end{tabular}

Table 6. Composition of trophic groups $(\% \pm \mathrm{SD})$ at the $\mathrm{R}, 0+$ and $1+$ zones in both between and under positions

\begin{tabular}{|lccrrrr|}
\hline Abundance (\%) & $\mathrm{R}_{\text {between }}$ & $\mathrm{R}_{\text {under }}$ & $0+_{\text {between }}$ & $0+_{\text {under }}$ & $1+_{\text {between }}$ & $1++_{\text {under }}$ \\
\hline Deposit feeders & $79 \pm 11$ & $75 \pm 2$ & $82 \pm 8$ & $71 \pm 8$ & $84 \pm 5$ & $85 \pm 4$ \\
Carnivores & $7 \pm 6$ & $1 \pm 2$ & $4 \pm 2$ & $7 \pm 2$ & $5 \pm 4$ & $4 \pm 1$ \\
Suspension feeders & $9 \pm 7$ & $10 \pm 10$ & $10 \pm 5$ & $12 \pm 4$ & $6 \pm 1$ & $6 \pm 3$ \\
Herbivores & $1 \pm 1$ & $2 \pm 3$ & $0 \pm 0$ & $0 \pm 0$ & $0 \pm 0$ & $0 \pm 0$ \\
Omnivores & $2 \pm 2$ & $3 \pm 2$ & $1 \pm 1$ & $4 \pm 3$ & $3 \pm 1$ & $3 \pm 1$ \\
Not determined & $2 \pm 4$ & $10 \pm 8$ & $3 \pm 3$ & $6 \pm 8$ & 3 \\
\hline
\end{tabular}

dominance of deposit feeders $(81 \%$ of all organisms, see Table 7).

\section{DISCUSSION}

We examined the influence of a 23 yr old mussel farm on the sediment and infaunal benthic community at multiple spatial scales. As a concomitant study (Callier et al. 2006) observed a greater flux of organic matter to the bottom in some zones and positions relative to others, we predicted that we would observe corresponding chemical and biological signatures.

\section{Sediment geochemical characteristics}

The flux of organic matter to the bottom in June and July ranged from 5 to $11 \mathrm{~g} \mathrm{OM} \mathrm{m}^{-2} \mathrm{~d}^{-1}$ at $\mathrm{R}$ and $1+{ }_{\text {under }}$ positions, respectively (Callier et al. 2006). This flux represents approximately 1 to $3 \mathrm{~g} \mathrm{C} \mathrm{m}^{-2} \mathrm{~d}^{-1}$, based on $30 \%$ carbon in organic matter (Holmer et al. 2005). Sedimentation rates of 1 to $5 \mathrm{~g} \mathrm{C} \mathrm{m}^{-2} \mathrm{~d}^{-1}$ may result in hypoxic sediments and increases in sulphate reduction around bivalve aquaculture sites (Dahlbäck \& Gunnarsson 1981). Thus, it was predicted that increased organic loading resulting from the presence of mussel lines would increase the organic content of the sedi- 
Table 7. Results of SIMPER analysis ( $\sqrt{ }$-transformed data) to show major differences in community structure among sample years. Average abundances $\left(\mathrm{N}\right.$, ind. $\left.\mathrm{m}^{-2}\right)$ and the \% contribution of the major taxa to within-year similarities (\%) are shown. Data compared are from 1975 (Bourget 1976, Bourget \& Messier 1982), 1978 (J. Munro et al. unpubl. data), 1982 (Élouard et al. 1983), 2003 (the present study) and 2004 (M. D. Callier at al. unpubl. data)

\begin{tabular}{|c|c|c|c|c|c|c|c|c|c|c|}
\hline & \multicolumn{2}{|c|}{1975} & \multicolumn{2}{|c|}{1978} & \multicolumn{2}{|c|}{1982} & \multicolumn{2}{|c|}{2003} & \multicolumn{2}{|c|}{2004} \\
\hline & $\mathrm{N}$ & $\%$ & $\mathrm{~N}$ & $\%$ & $\mathrm{~N}$ & $\%$ & $\mathrm{~N}$ & $\%$ & $\mathrm{~N}$ & $\%$ \\
\hline \multicolumn{11}{|l|}{ Carnivores } \\
\hline Retusa canaliculata & 924 & (49) & 1296 & $(10)$ & 260 & $(30)$ & 21 & & 827 & (50) \\
\hline \multicolumn{11}{|l|}{ Suspension feeders } \\
\hline Spisula spp. & 105 & (12) & 123 & & 2361 & $(27)$ & & & & \\
\hline Ensis directus & 5 & & 1123 & & 1 & & 25 & $(6)$ & 4 & \\
\hline Mya arenaria & & & 33696 & $(58)$ & & & 55 & (3) & & \\
\hline \multicolumn{11}{|l|}{ Omnivores } \\
\hline Nephtys sp. & 46 & (17) & 33 & & 14 & (12) & 4 & & 29 & \\
\hline Nereis sp. & & & 3 & & 4 & & 22 & (3) & & \\
\hline \multicolumn{11}{|l|}{ Deposit feeders } \\
\hline Tellina agilis & 167 & (8) & 1897 & (11) & 164 & $(10)$ & 19 & (3) & 49 & (4) \\
\hline Pectinaria granulata & 110 & (5) & 153 & (4) & & & 151 & (10) & 5 & \\
\hline Nassarius trivittatus & 18 & & 9 & & 14 & (11) & 11 & $(2)$ & 147 & (21) \\
\hline Polydora sp. & & & 1188 & (10) & 1 & & 64 & (9) & 29 & \\
\hline Capitellidae & & & 85 & & 6 & (3) & 202 & (23) & 76 & (10) \\
\hline Hydrobia minuta & & & 14 & & 2 & & 106 & $(4)$ & 79 & (8) \\
\hline Macoma sp. & & & 33 & & & & 355 & (30) & 22 & \\
\hline
\end{tabular}

ments and consequently lead to a localized reducing environment characterized by negative redox potentials and increased sulphide concentrations in the sediments. However, none of the sediment characteristics varied significantly among zones or positions.

It was predicted that the greatest \%OM would be observed in $1++_{\text {under }}$ sediments, where the greatest sedimentation rates were recorded (Callier et al. 2006). Although the average \%OM at the $-1 \mathrm{~cm}$ depth tended to be greatest at $1+_{\text {under }}$ sites (see Fig. 2), this was not statistically significant. The analysis of the labile component of the $\mathrm{OM}$ in the 0 to $0.5 \mathrm{~cm}$ of the sediment surface, where the biodeposits accumulate, would have probably been a more appropriate method to detect difference between zones (Nickell et al. 2003). White mats, likely the sulphur bacteria Beggiatoa spp., were observed directly under the $1+$ mussel lines (pers. obs.), as they have been in mussel culture sites elsewhere (Grant et al. 1995). The presence of Beggiatoa indicates that reducing conditions have reached the sediment-water interface at those sites (Holmer et al. 2005)

Sediment sulphide concentrations increased with depth at all sites and were typically $>2000 \mu \mathrm{M}$, indicating hypoxic benthic conditions (Wildish et al. 1999). Redox potentials decreased slightly with depth, as is expected in muddy and silty habitats (Diaz \& Rosenberg 1995). However, both parameters did not differ among zones. Sediment redox potential and sulphide levels can be used to detect the effects of high organic loading under fish cages (Hargrave et al. 1997, Ander- son et al. 2005), but were probably not sensitive enough to detect the effect of mussel biodeposition. Other recent studies on bivalve aquaculture have reached the same conclusion (Anderson et al. 2005, Miron et al. 2005). Anderson et al. (2005) suggested that in depositional environments where the content of organic matter is naturally high, biodeposition from cultured bivalves does not significantly affect these parameters.

Relatively small increases in sedimentation, as measured in GEL by Callier et al. (2006), may have been obscured by background processes. Giles et al. (2006) suggested that rapid mineralization of mussel biodeposits in mussel farms may lead to a decoupling of sedimentation and sediment characteristics. Detritus from other sources within culture sites, such as plankton, seagrass or biodeposits from species associated with the cultured species (Stenton-Dozey et al. 2001), may further obscure the influence of mussel biodeposition. For example, Giles (2006) has estimated that only $14 \%$ of the increased biodeposition within a mussel culture site in New Zealand was due to mussel faeces biodeposition.

\section{Benthic community}

Subtle changes in environmental conditions may be reflected in altered biomass or species composition of macrofaunal communities before they are detectable in sediment chemical properties (Weston 1990, Edgar et al. 2005). This was observed in the current study 
using both univariate and multivariate indices; the observed differences were likely due to differences in deposition rates among zones and positions.

Although not statistically significant, the abundance of benthic fauna tended to be greatest in the $0+$ zone. Biomass was greatest in 0+ sites, largely due to the presence of Nephtys caeca, Nassarius trivittatus, Pectinaria granulata, and juvenile Nereis spp. that probably benefit from the moderate organic loading. Various responses have been observed in terms of biomass at mussel farms. Kaspar et al. (1985) did not detect a pattern with respect to biomass but other studies have observed either lower (Stenton-Dozey et al. 1999) or greater (de Jong 1994, Grant et al. 1995) biomass under mussel farms, the latter being due at times to the presence of scavengers attracted by mussel drop-off.

All measures of diversity evaluated $\left(S, H^{\prime}\right.$ and $\left.J^{\prime}\right)$ were reduced in the $1+$ zone and $S$ and $H^{\prime}$ were greatest in the 0+ zone. Other studies have reported decreases in $S$ and $H^{\prime}$ (Mattsson \& Lindén 1983, Kaspar et al. 1985, Stenton-Dozey et al. 1999, Chamberlain et al. 2001) of benthic macrofaunal communities under mussel cultures. Low $H^{\prime}$ in the 1+ zone resulted from the low number of species present. The dominance of the Capitella capitata at $1+$ under positions and of juvenile Macoma calcarea at $1+_{\text {between }}$ positions further contributed to the low $H^{\prime}$ and accounted for the low $J^{\prime}$ values in the $1+$ zone.

In the present study, the analysis of trophic structure was not useful for detecting differences between mussel farm and reference zones as the communities in all zones were dominated by deposit feeders, indicating a generally enriched environment. This is likely related to the high level of organic sedimentation in the lagoon (1 to $3 \mathrm{~g} \mathrm{C} \mathrm{m}^{-2} \mathrm{~d}^{-1}$ ). Benthic communities in organically enriched areas are typically dominated by deposit feeders (Pearson \& Rosenberg 1978) while suspension feeders often dominate less organically rich environments, as organic debris may have a smothering impact, preventing them from thriving (Kaspar et al. 1985). The results obtained from studies on trophic structure in mussel farms are inconsistent. Mattsson \& Lindén (1983) observed higher abundances of deposit feeders at mussel culture sites compared to reference sites. In contrast, others have observed a dominance of predators and carnivores under mussel farms (de Jong 1994, Grant et al. 1995, Stenton-Dozey et al. 1999) that profit from mussel drop-off. Thus, care should be taken in using deposit feeders as indicators of organic enrichment at bivalve farms. This is particularly true in coastal areas where many such farms are located and which have naturally organically enriched sediments (Miron et al. 2005).

Although effects were not detected with trophic structure analysis, species-level effects were apparent in this study at both large and small spatial scales. Macoma calcarea was, overall, dominant in all sites in 2003. However, the initial spatfall and distribution of Macoma sp. has been shown to be largely a function of hydrodynamic processes (Armonies \& HellwigArmonies 1992). The juveniles then undergo a secondary dispersal into low intertidal and infralittoral areas. Their importance in signalling organic inputs is therefore doubtful and they are not discussed further.

$\mathrm{R}$ and $0+$ zones were dominated by Polydora ciliata, Pectinaria granulata, and Heteromastus filiformis with Hydrobia minuta also being dominant in the 0+ zone. Some species, such as $H$. minuta, may have benefited from the moderate organic loading in the $0+$ zone. This was apparent by their great abundance there and near absence in other zones. Other abundant species, such as $P$. granulata and $P$. ciliata, are generally abundant in both the $0+$ and reference zones and may reflect a general enrichment of the lagoon as they are characteristic of an intermediate stage of organic enrichment (Pearson \& Rosenberg 1978). Communities differed at small spatial scales but only within the 1+ zone. $1+t_{\text {between }}$ positions were dominated by $P$. ciliata and Capitella capitata while at $1+_{\text {under }}$ positions $P$. ciliata was absent and C. capitata increased in abundance by more than a factor of 12. This suggests a shift from an intermediately enriched environment between mussel lines to a greatly enriched stage directly under the $1+$ under lines, only $10 \mathrm{~m}$ distant. Such a switch between $P$. ciliata and C. capitata has been described in the past (Pearson \& Rosenberg 1978), with P. ciliata living at the edge of an enriched area dominated by $C$. capitata. $C$. capitata is a non-specialized surface deposit feeder and has some resistance to sulphide toxicity and hypoxia (Diaz \& Rosenberg 1995).

A number of biological interactions may also explain the absence of other species at 1+ sites. The mussels may have had indirect effects on infaunal community structure by feeding on the larvae of infauna (Woodin 1976) and generally decreasing food resources (Peterson \& Black 1987). In contrast, Commito \& Boncavage (1989) have shown that mussels do not affect the abundance of infaunal species that do not disperse as planktonic larvae. Capitella sp. produces broods of 30 to 400 eggs which develop into lecithotrophic larvae that are competent to settle almost immediately after being released by female worms (Linton \& Taghon 2000), possibly partly explaining the abundance of this species in $1+_{\text {under }}$ positions. Predation by large invertebrates attracted by the presence of fallen mussels (de Jong 1994, Grant et al. 1995) may also have an influence on the infauna. For example, lobsters were observed feeding on razor clams Ensis directus in the culture site during this study. 
Since benthic effects as described above may be limited to the areas directly under the mussel lines, remote methods (i.e. ship-deployed) are likely to be less efficient for detecting such localized effects. Studies using direct sampling methods (i.e. SCUBA divers) have often observed accumulations of scavengers attracted by mussel drop-off (e.g. de Jong 1994, Grant et al. 1995) that have not been observed using remote methods. This may have an impact on our perception of the role of bivalve culture on the benthic environment and make comparisons between studies difficult.

\section{Historical data}

The present study showed localized effects of mussel culture. The comparison between $1+_{\text {under }}$ and $1+_{\text {between }}$ positions that were only $10 \mathrm{~m}$ apart showed that nearfield benthic effects were likely due to the biodeposition of the mussels and not other intrinsic features within the zone. However, all zones showed some indications of organic enrichment and it is difficult to determine if the benthic communities at the $0+$ and $\mathrm{R}$ zones were under a diffuse and broader influence of the mussel farm or if the mussel farm had no influence on those zones. Indeed, there are a number of factors that may explain such general organic enrichment in GEL. The lagoon is a very complex system as various modifications have occurred within it over the past half century. A causeway that separates GEL from the lagoon to the south (see Fig. 1) was constructed in 1947. A navigation channel was dredged in the 1980s for a port constructed in GEL. Islands were also constructed with the material dredged during this activity (e.g. the island next to the opening of the channel in Fig. 1). Commercial mussel farming was initiated in the early 1980s. Traditional ecological knowledge also suggests that Zostera marina beds have expanded considerably in recent years. Separating the importance of these different factors, which may modify currents and/or sedimentation rates and thus benthic community structure, is difficult.

To address this question, the benthic communities observed in the present study were compared to others conducted before the mussel farm was established $(1975,1978)$, at the start of farming activities (1982), and after the 1+ mussels were harvested (2004). Although the comparison was difficult because of differences in site locations (see Fig. 1) and sampling methods, some observations could be made. Benthic communities differed among years, but 1975, 1982, and 2004 were similar. Retusa canaliculata and Tellina agilis were very abundant in all years except 2003. This Retusa-Tellina association has been previously observed in neighbouring Prince Edward Island (see
PEI, Fig. 1) by Hughes \& Thomas (1971). They also mentioned the presence of a Yoldia-Tellina association with $R$. canaliculata and Pectinaria granulata for deeper sites. Miron et al (2005) also reported that the gastropods $R$. obtusa and Nassarius trivittatus and the bivalves $T$. agilis and Yoldia limatula were the dominant species at mussel farm sites in PEI (Fig. 1).

The 2003 community was dissimilar to the others largely due the absence of the suspension feeder Spisula spp., the lesser abundance of the carnivore Retusa canaliculata and the greater abundance of Capitellidae and Macoma sp. Weisberg et al. (1997) indicated that Spisula sp., Retusa sp. and Macoma sp. are pollutionsensitive taxa, while Capitellidae is a pollution-tolerant family. As discussed above, the great abundance of Macoma calcarea in 2003 was probably due to their recruitment to the deeper part of the lagoon, as $M$. calcarea is a typical intertidal species (Bourget 1976). The absence of Spisula spp., a large active suspension feeding bivalve, is possibly explained by greater organic input related to mussel farming. One yr after the mussel harvest (2004), Capitella capitata was almost absent, indicating that the organic enrichment decreased rapidly. However, the presence of the deposit feeders Nassarius trivittatus, Heteromastus filiformis and Hydrobia minuta in 2004 indicates that the sediment was still organically rich.

Bourget (1976) and Bourget \& Messier (1982) suggested that the low benthic diversity and biomass in the middle of GEL was characteristic of an 'unstable community'. They also compared the biomass of the benthos in GEL to other regions and found that it was considerably lower than that observed elsewhere (e.g. PEI). In 1978, Munro et al. (unpubl. data) observed lower macrofaunal diversity and abundance in the deeper part as compared to other parts of the lagoon. They also found that the sites $>4$ m deep were characterized by a greater proportion of mud than other parts of the lagoon. Water currents are reduced in the deeper parts of the lagoon and water turnover in the area, where the mussel farm is located, is ca. 25-40 d (Koutitonsky \& Tita 2006). This relatively low flushing rate likely contributes to the general hypoxic conditions of the sediment, especially when winds are weak and water temperatures high, as observed in August. Degradation of seagrass and algae detritus during the ice-covered winter months may further contribute to the general hypoxia of the deeper parts of the lagoon.

Irrespective of the source of variation among infaunal communities among sampling periods (before, at the start of and following $>20$ yr of mussel farming), several observations may be made. First, macrobenthic community samples taken from each of these 3 periods are, at times, quite similar. Second, differences in community structure between years within periods are at 
least as large as differences among community structures among periods. Together, this suggests that any impacts associated with aquaculture, at decadal temporal scales, will be hidden by natural temporal variation in benthic macrofaunal community structure. The data from the current study showing a preponderance of deposit feeders in 2003, especially in the $1+_{\text {under }}$ position, suggest that mussel aquaculture does have local enrichment effects. However, any such effects seem to disappear within $1 \mathrm{yr}$, as indicated by the structure of benthic communities in 2004 .

Acknowledgements. We thank the MAPAQ and DFO personnel on the Magdalen Islands, as well as A. Weise, F. Hartog, P. Archambault, C. Langevin, J. Tomac, M. Richard, F. Roy, P. Robichaud, G. Tita, M. Léonard and J. Chopelet. Thanks also to our boat captains, G. Arseneau and R. Lavallée; to C. Éloquin and associates, who gave us access to their mussel farm; to J.-M. Gagnon, who identified juvenile bivalves; to Dr. E. Bourget and J. Munro for providing us the raw 1975 and 1978 data; and to Drs. G. Stora and F. Olivier for providing information on some macrofaunal species. The manuscript was improved upon by comments from A. Weise. This study was supported by the Aquaculture Collaborative Research and Development Program (ACRDP), the Société de Développement de l'Industrie Maricole (SODIM) and by Fisheries and Oceans Canada.

\section{LITERATURE CITED}

Anderson MJ, Ter Braak CJF (2003) Permutation tests for multi-factorial analysis of variance. J Stat Comput Sim 73: 85-113

Anderson MR, Tlusty MF, Pepper VA (2005) Organic enrichment at cold water aquaculture sites: the case of coastal Newfoundland. Environmental Effects of Marine Finfish Aquaculture. In: Hargrave BT (ed) The handbook of environmental chemistry, Vol 5. Springer, Berlin, p 99-113

Andrew NL, Mapstone BD (1987) Sampling and the description of spatial pattern in marine ecology. Oceanogr Mar Biol Annu Rev 25:39-90

Armonies W, Hellwig-Armonies M (1992) Passive settlement of Macoma balthica spat on tidal flats of the Wadden Sea and subsequent migration of juveniles. Neth J Sea Res 29: 371-378

Bourget E (1976) Impact écologique de la fermeture de la baie de Grosse Isle. I.-M., et de sa saturation éventuelle en sel, Institut national de la recherche scientifique-Centre océanographique de Rimouski, Rimouski

Bourget E, Messier D (1982) Macrobenthic density, biomass, and fauna of intertidal and subtidal sand in a Magdalen Islands lagoon, Gulf of St. Lawrence. Can J Zool 61: 2509-2518

Byers SC, Mills EL, Stewart PL (1978) A comparison of methods of determining organic carbon in marine sediments, with suggestions for a standard method. Hydrobiologia 58: $43-47$

Callier MD, Weise AM, McKindsey CW, Desrosiers G (2006) Sedimentation rates in a suspended mussel farm (GreatEntry Lagoon, Canada): biodeposit production and dispersion. Mar Ecol Prog Ser 322:129-141

Chamberlain J, Fernandes TF, Read P, Nickell TD, Davies IM (2001) Impacts of biodeposits from suspended mussel (Mytilus edulis L.) culture on the surrounding surficial sediments. ICES J Mar Sci 58:411-416

Commito JA, Boncavage EM (1989) Suspension-feeders and coexisting infauna: an enhancement counterexample. J Exp Mar Biol Ecol 125:33-42

Dahlbäck B, Gunnarsson LÅH (1981) Sedimentation and sulfate reduction under a mussel culture. Mar Biol 63: $269-275$

de Jong RJ (1994) The effects of mussel farming on the benthic environment. MSc thesis, University of Auckland

Diaz RJ, Rosenberg R (1995) Marine benthic hypoxia: a review of its ecological effects and the behavioural responses of benthic macrofauna. Oceanogr Mar Biol Annu Rev 33:245-303

Edgar GJ, Macleod C, Mawbey RB, Shields D (2005) Broadscale effects of marine salmonid aquaculture on macrobenthos and the sediment environment in southeastern Tasmania. J Exp Mar Biol Ecol 327:70-90

Élouard B, Desrosiers G, Brêthes JC, Vigneault Y (1983) Étude de l'habitat du poisson autour des îlots créés par des deblais de dragage; lagune de Grande-Entrée, Îles-de-laMadeleine. Can Tech Rep Fish Aquat Sci 1209

Giles H (2006) Dispersal and remineralisation of biodeposits: Ecosystem impacts of mussel aquaculture. $\mathrm{PhD}$ thesis, The University of Waikato, Hamilton

Giles H, Pilditch CA (2004) Effects of diet on sinking rates and erosion thresholds of mussel Perna canaliculus biodeposits. Mar Ecol Prog Ser 282:205-219

Giles H, Pilditch CA, Bell DG (2006) Sedimentation from mussel (Perna canaliculus) culture in the Firth of Thames, New Zealand: Impacts on sediment oxygen and nutrient fluxes. Aquaculture 261:125-140

Grant J, Hatcher A, Scott DB, Pocklington P, Schafer CT, Winters GV (1995) A multidisciplinary approach to evaluating impacts of shellfish aquaculture on benthic communities. Estuaries 18:124-144

Hargrave BT (ed) (2005) Environmental effects of marine finfish aquaculture. The handbook of environmental chemistry, Vol 5. Water pollution, Part M. Springer-Verlag, Berlin

Hargrave BT, Phillips GA, Doucette LI, White MJ, Milligan TG, Wildish DJ, Cranston RE (1997) Assessing benthic impacts of organic enrichment from marine aquaculture. Water Air Soil Poll 99:641-650

Hatcher A, Grant J, Schofield B (1994) Effects of suspended mussel culture (Mytilus spp.) on sedimentation, benthic respiration and sediment nutrient dynamics in a coastal bay. Mar Ecol Prog Ser 115:219-235

Haven DS, Morales-Alamo R (1966) Aspects of biodeposition by oysters and other invertebrate filter feeders. Limnol Oceanogr 11:487-498

Holmer M, Wildish DJ, Hargrave B (2005) Organic enrichment from marine finfish aquaculture and effects on sediment biogeochemical processes. In: Hargrave BT (ed) The handbook of environmental chemistry, Vol 5. Water pollution, Part M. Springer-Verlag, Berlin, p 181-206

Hughes RN, Thomas MLH (1971) The classification and ordination of shallow-water benthic samples from Prince Edward Island, Canada. J Exp Mar Biol Ecol 7:1-39

Kaspar HF, Gillespie P, Boyer LF, MacKenzie AL (1985) Effects of mussel aquaculture on the nitrogen cycle of benthic communities in Kenepuru Sound, Marlborough Sound, New Zealand. Mar Biol 85:127-136

Koutitonsky VG, Tita G (2006) Temps de renouvellement des eaux dans la lagune de Grande-Entrée aux Îles-de-laMadeleine Ministère de l'Agriculture, des Pêcheries et de l'Alimentation du Québec, Rapport de recherchedéveloppement 151 
Linton DL, Taghon GL (2000) Feeding, growth, and fecundity of Capitella sp. I in relation to sediment organic concentration. Mar Ecol Prog Ser 205:229-240

Mattsson J, Lindén O (1983) Benthic macrofauna succession under mussels, Mytilus edulis L. (Bivalvia), cultured on hanging long-lines. Sarsia 68:97-102

Miron G, Landry T, Archambault P, Frenette B (2005) Effects of mussel culture husbandry practices on various benthic characteristics. Aquaculture 250:138-154

Nickell LA, Black KD, Hughes DJ, Overnell J, Brand T, Nickell TD, Breuer E, Harvey SM (2003) Bioturbation, sediment fluxes and benthic community structure around a salmon cage farm in Loch Creran, Scotland. J Exp Mar Biol Ecol 285-286:221-233

Pearson TH, Rosenberg R (1978) Macrobenthic succession in relation to organic enrichment and pollution of the marine environment. Oceanogr Mar Biol Annu Rev 16:229-311

Peterson CH, Black R (1987) Resource depletion by active suspension feeders on tidal flats: influence of local density and tidal elevation. Limnol Oceanogr 32:143-166

Stenton-Dozey JME, Jackson LF, Busby AJ (1999) Impact of mussel culture on macrobenthic community structure in

Editorial responsibility: Howard Browman (Associate Editorin-Chief), Storebø, Norway
Saldanha Bay, South Africa. Mar Pollut Bull 39:357-366

Stenton-Dozey J, Probyn T, Busby A (2001) Impact of mussel (Mytilus galloprovincialis) raft-culture on benthic macrofauna, in situ oxygen uptake, and nutrient fluxes in Saldanha Bay, South Africa. Can J Fish Aquat Sci 58: 1021-1031

Weisberg SB, Ranasinghe JA, Schaffner LC, Diaz RJ, Dauer DM, Frithsen JB (1997) An estuarine benthic index of biotic integrity (B-IBI) for the Chesapeake Bay. Estuaries 20:149-158

Weston DP (1990) Quantitative examination of macrobenthic community changes along an organic enrichment gradient. Mar Ecol Prog Ser 61:233-244

Wildish DJ, Akagi HM, Hamilton N, Hargrave BT (1999) A recommended method for monitoring sediments to detect organic enrichment from mariculture in the Bay of Fundy. Can Tech Rep Fish Aquat Sci, 2286

Woodin SA (1976) Adult-larval interactions in dense infaunal assemblages: patterns of abundance. J Mar Res 34:25-41

Word JQ (1990) The infaunal trophic index, a functional approach to benthic community analyses. PhD thesis, University of Washington, Seattle

Submitted: November 15, 2006; Accepted: May 6, 2007 Proofs received from author(s): September 24, 2007 